JMKSP (Jurnal Manajemen, Kepemimpinan, dan Supervisi Pendidikan)

Volume 7 Issue 1 (2022) Page 19-34

ISSN 2614-8021 (Online) 2548-7094 (Print)

\title{
Digital Literacy Governance Management in SMA Negeri Sumatera Selatan
}

\author{
Diarani Ariesta Wulandari' ${ }^{1}$, Yasir Arafat ${ }^{2}$, Rohana ${ }^{2}$ \\ ${ }^{1}$ SMA Negeri Sumatera Selatan \\ ${ }^{2}$ Universitas PGRI Palembang \\ Corresponding Author E-mail: diarani.ariesta@gmail.com
}

Received 25 July 2021; Revised 2 September 2021; Accepted 2 January 2022

\begin{abstract}
The objective of this research is to find out the implementation of digital literacy governance management in Senior High school. This research is qualitative case study method. The result shows that management of digital literacy governance in SMA Negeri Sumatera Selatan is conducted through four management functions which are planning, organizing, actuating and controlling. Planning process described by research, meetings, proposal design, and policy determination. The forming of committee for SMA Rujukan program performs the organizing process. The actuating process shown by the implementation of digital literacy strategies formulated by Indonesia Ministry of Education and Culture. The controlling process is not applied to all teachers, staff and students but can be seen through the supervision and evaluation of SMA Rujukan program, teacher's supervision, and survey's result of library and IT divisions from students.
\end{abstract}

Keyword: Digital Literacy, Management, Governance

\section{Introduction}

Indonesia was in the third position in the world for using social media based on wearesocial.com in January 2020 and fifth position as a mobile internet user. In 2020, the number of smartphone users in Indonesia reach 170 million people. This indicates Indonesia as one of countries with the largest number of 
internet users in the world with an increase of $17 \%$ from 2019. This phenomenon provides challenges as well as opportunities for the development of digital literacy.

Regulation of the Minister of Education and Culture Number 23 of 2015 formulates the character building as the activity to accustom the positive attitudes and behavior in school. One of the implementations of character building is literacy activity, including digital literacy (Ratih \& Aline, 2015). Law of the Republic of Indonesia Number 14 of 2005 states that teachers are educators who have obligations to improve and develop their competencies and curriculum qualifications coincide with the development of ICT (Information and Communication Technology) (JDIH, 2017). One of the competencies for a professional teacher is the ability to use ICT because teachers are not the only learning resources today. The development of information technology has made the learning resources grow wider and being unlimited (Erwin, Arafat \& Wardiah, 2021). Digital literacy is very important in Industry 4.0 as well as reading, writing and calculation. Nowadays, people use digital technology to get information quickly. The rapid of digital information demands all school elements, including students, to be more careful in sorting out the high-quality informations. According to O'Brien and Scharber (2008), digital literacy can be used in actual learning. Digital media has the potential as a teaching material that gives authentic description, increases the reading enthusiasm outside of school hours, increases self-confidence as a good reader, and fosters the actual reading sources usage.

SMA Negeri Sumatra Selatan appointed by government as one of SMA Rujukan in South Sumatra, has applied digital literacy in learning. SMA Rujukan is Senior High Schools that have complied or exceeded the National Education Standard such that they can be reference to other schools (Kemendikbud, 2018). SMA Negeri Sumatra Selatan has made several programs that encourage teachers, staff and students to apply digital literacy. It has sufficient digital facilities such as internet network, projectors, smart boards, tablets, and computer rooms. For communication system, the employees and students use email, WhatsApp, intranet and recently SIMASTER (Integrated School Management Information System) as digital data center. In addition, the XI and XII graders have carried out 
digital system for final semester examination. Most of teachers have applied digital literacy but some of teachers need more motivation in implementing digital literacy learning. Some staff are also not familiar with digital communication and administration process, so they need more motivation and guidance. Some students still don't have skill for using digital facilities nor have the digital tools, so they often do digital learning in groups which is not effective. Many students come from remote districts where they never use technology in learning before, so they need special treatment from school.

Therefore, this article examines the implementation of digital literacy management in SMA Negeri Sumatra Selatan. The focus is the process of planning, organizing, implementing and controlling digital literacy in SMA Negeri Sumatra Selatan and how it fits to management process and digital literacy strategy that has made by government.

The school literacy is one of the government programs in the framework of character building as stated in the regulation of Minister of Education and Culture number 23 of 2015 (Kemendikbud, 2016). This program is one of platforms to maximize the various potential of students where school can help them to identify and develop their talents and capabilities. School literacy has been implemented by schools in Indonesia since 2015 with the initial movement of fostering the interest of reading (Antoro, 2017). Reading skill is important to master knowledge better (Kartini \& Yuhana, 2019). In its development, school literacy has penetrated into Reading Book Movement and parents-public involvement. The impact of school literacy can be seen from the changes of mindset and behavior, including the shaping of good values for students.

The development of technology and information has brought the young generation into digital world. One of digital literacy characteristics is the conversion of physical reading to digital. According to Gilster (1997), digital literacy is defined as the ability to understand and use information in various forms from a very wide variety of sources accessed from computer devices. Buckingham in Kurnia, et al. (2017) states that the concept of digital literacy is not only related to the technique of using computers but also knowledge and emotions in using digital media and devices including the internet. In Supporting 
Materials for Digital Literacy book published by the Ministry of Education and Culture, basic principles of developing digital literacy include: 1) the ability to extract ideas implicitly and explicitly from the media; 2) the interdependence between media tools which complement each other; 3) the information sharing system that not only shows identity but also creates a meaningful message; 4) the ability to understand the value of information and how to store it accessibly for the long term utilization (Kemendikbud, 2017). In this competitive era, school has to provide students with knowledge, information and technology (Nopilda \& Kristiawan, 2018). The application of digital literacy in schools is developed as a learning mechanism integrated to curriculum and digital technology usage in the school system. In this case, teachers need to increase their knowledge and creativity in the digital literacy teaching process. Both teachers and staff also need to develop themselves in the use of digital media. Ministry of Education and Culture proposes 5 strategies for school, including teachers and staff, to apply digital literacy: 1) strengthening the facilitators' capacities through training programs; 2) increasing the number and variety of high-quality learning resources so that teachers and students can create the learning system optimally; 3) expanding the access to high-quality learning resources and the coverage of learning participants, such as providing computers and internet access; 4) increasing the public involvement such as the experts of ICT, government, parents and communities; 5) strengthening school governance with e-administration system and digital literacy policies (Kemendikbud, 2017).

The management process includes planning, organizing, implementing and controlling (Terry in Isnandari, 2016:14). Educational governance is the utilization of needed resources to achieve the quality education improvement (Nurfadillah, 2018:6). Digital literacy governance management is related to planning, organizing, implementing and controlling the digital literacy programs in schools. Digital literacy management is digital literacy activities held in schools by utilizing all resources to improve the quality of school education. The application of digital literacy is not only about learning but also strengthening capacity, increasing the number and variety of learning resources, expanding 
access, strengthening public involvement, and strengthening governance (Kemendikbud, 2017).

A similar research was done by Amalia (2015) about digital literacy of Senior High School students in concerning of using internet, Saputra (2018) about the use of Blog in learning for Junior High School Students, Adityar (2017) about the effect of Digital Literacy on risky internet behavior for Senior High School students, Sholihah (2018) about the use of e-journal for college students, and Melani (2019) about the implementation of Digital Literacy in Islamic Education learning for Senior High School students. This research is about the process of management for implementing digital literacy in Senior High School.

\section{Methods}

In this study, researcher used a case study method with a qualitative approach. According to Sugiyono (2012), qualitative research is a method to examine the condition of natural objects where the researcher is the key instrument with data collection technique done by triangulation. Data analysis is inductive/qualitative and the research result emphasize more on value. This research is a qualitative case study method that examines the field phenomenon deeply. The case study is digital literacy management in SMA Negeri Sumatra Selatan. According to Rahardjo (2017), the case study method is carried out naturally, holistically and deeply. Natural is defined as the activity for obtaining the data in the real-life context without specific treatment for the subject or the context of study. Holistic means that the information must be comprehensive. Depth method means the process of exploring the information deeply, not only from the informants and main participants, but also from the people around the research subject.

The data collection technique for qualitative research is conducted by triangulation which is combination of observation, interviews and documentation. The observation in this study is a passive observation. According to Sugiyono (2012), the passive observation means that researcher is independent, not involved in the activities. The interview is a semi-structured including in-depth interviews in order to find problems more openly through the opinions and ideas expressed 
by the informants (Sugiyono, 2012). Document is records of past events (Sugiyono, 2012). The documentation process is the phase in collecting data. The documents collected in this study are regulations, policies, and photos.

\section{Results and Discussion}

SMA Negeri Sumatra Selatan was appointed by the government, Directorate of Senior High School Development, through the South Sumatra Education Department as one of the SMA Rujukan (Referral High Schools) in 2016. As SMA Rujukan, SMA Negeri Sumatra Selatan implements several programs which are Referral School socialization, workshops, in-house training, character building, local content development, safe schools program including the literacy development. In 2018, the book literacy movement developed into digital literacy. Digital literacy is carried out together with technology development that makes the literacy process becomes an activity involving the use of technology, information and communication devices and the ability to socialize, learn, behave and think critically, creatively and inspire (Kemendikbud, 2017:8). The application of digital literacy in SMA Negeri Sumatra Selatan is not only in learning, but also in the administration and dormitory management.

\section{Planning}

Planning is a guideline for implementation and control, determining a strategy or framework to achieve certain goals (Kristiawan \& Safitri \& Lestari, 2017). The planning for conducting the digital literacy program in SMA Negeri Sumatra Selatan consists of the discussions between the principal and the deputy head of school and provincial education office about determination, goals formulation, and concept design. The research process and data or information collection are carried out in a SWOT analysis, strategic issues formulation and school's mid-term work plan. The next steps are making a decree and meeting with teachers, staff and main committees in drafting a program concept. Furthermore, making a proposal as a first step in formulating the form of activities, funding and committee. 


\section{Organizing}

The arrangement of the organizational structure for the implementation of SMA Rujukan program is decided in a meeting between the principal and the deputies. The committees in SMA Rujukan also includes committees for digital literacy programs. This committee is led by the Deputy Principal of Public Relations and the members consists of teachers and staff. The organizing of digital literacy is also driven by other divisions. The committee for SMA Rujukan programs organize the formulation and concept development for 4C (Creative, Collaboration, Communicative, Critical thinking) skill-based lesson plan development training, e-modules training, e-report training, literacy socialization, learning video creation and scientific papers writing. The committee outside of SMA Rujukan are academics, IT, library, public relations and operational divisions. The academics team lead the teachers to make and develop digital technology-based learning concepts. Library division manage digital learning resources, digital reading materials and digital facilities. ICT division manage the availability of digital facilities, intranet and SIMASTER application. Public relations team manage social media and operational team manage the digital administration system in SMA Negeri Sumatra Selatan.

\section{Implementing}

The implementation process is the essence, which is a very important part of the management process (Kristiawan \& Safitri \& Lestari, 2017). In this process, each individual makes interactions according to their job to achieve the organization's goals. The implementation of digital literacy program in SMA Negeri Sumatra Selatan is based on the strategy of digital literacy formulated by the Indonesian Ministry of Education and Culture which are strengthening the capacity of facilitators, increasing the number and variety of quality learning resources, expanding access to learning resources and coverage of learning participants, increasing public involvement and strengthening governance. A strong literacy culture will affect the success of students at school and environment (Wandasari, 2017). 
The focus of strengthening the capacity of facilitators is training about utilization of ICT for school development for principal, supervisors, teachers and staff. Training activities for teachers are e-report training, e-modules training, online quizzes training, lesson plans training based on $4 \mathrm{C}$ which include the use of ICT in learning, and making learning videos. Slims 8 application training was held specifically for librarians and SIMASTER application training which was attended by teachers and staff. In addition, the use of ICT is also applied in making scientific papers for students guided by teachers. All training activities were also attended by principal and supervisors. Some teachers take digital technology training outside of school on their own initiative.

Increasing the number and variety of quality learning resources includes the addition of digital literacy reading materials in the library, the provision of educational sites as learning resources for school members, and the use of educational applications as learning resources for school members aim to keep up with the increasingly rapid development of science along with technological advances (Kemendikbud, 2017). The additional procurement of digital literacy reading materials in library is included into the additional of general reading materials that is usually proposed by teachers, especially ICT teachers and students who are interested in digital technology. Until now, there is a special shelf for reading materials about digital or ICT and a special cabinet for reading materials on $\mathrm{CD}$ in library. The provision of e-books is provided through the school intranet. However, there were only a few students who use CD as reading materials. This is because students are not interested and there is limited access such as the CD collections can only be accessed by 12 graders. Likewise, some students have difficulty accessing e-books on the intranet due to network or tokens constraints. Digital learning aids as learning resources are often accessed by students via computers and tablets that have been provided in the library.

SMA Negeri Sumatra Selatan has not officially provided educational sites as suggested by the government such as Ruang belajar, Ruang Guru, Sahabat Keluarga, or Sekolah Aman for teachers, staff and students as a source of learning and school development information (Kemendikbud, 2017). As an alternative, the school create an intranet as a data center where there are collections of learning 
material provided by teachers. Some teachers and students independently access educational sites such as Zenius, Ruang Guru, Schoology, Edmodo and Youtube as references for learning. Teachers, staff and students have used educational applications as suggested by the government but it's not run optimally. It can be seen that there were only two training sessions about learning applications which are Kahoot and Quipper. Some teachers and students use educational applications independently such as Ruang Guru and Zenius. The use of technology in learning helps teacher to create the atmosphere of enthusiasm and activeness at class (Primasari, Maryani, Suparmanto \& Juwita, 2019).

Wall magazine has function as media for students to inform such as competitions and student activities. Student Council often provides the information of science or knowledges articles but rarely on digital themes. The articles about digital content usually are shared by ICT division of Student Council. Nowadays, science and technology are developing very fast and digital technology has a significant role in learning (Muhasim, 2017). The School wall magazine and classroom wall magazines have potency to be one of the information center for students, so it would be better if school optimize them as medias to share information about technology and digital literacy with regular schedule.

Expanding access to high-quality learning resources and coverage of learning participants includes the provision of digital technology devices that support digital learning system and digital media as information center. The provision of digital technology equipment in SMA Negeri Sumatra Selatan is quite complete. They have computers in library, ICT and language room, computers for staff, laptops for teachers, tablets, projectors, smart boards, LCDs, and internet where the network almost in all school buildings except dormitories. Internet access is very useful for teachers, staff and students for the implementation of digital literacy. Somehow, they need more computers for student assessment and learning. Some devices such as smart boards need to be fixed so they can be used again. A flexible schedule for students to use the school's computers are also needed especially for students who do not have their own computer devices. 
SMA Negeri Sumatra Selatan does not have digital screen or board as one of media for delivering information to school members as mentioned by government. However, there are Smart TV in the main lobby and library. This television devices were once used to display school profile videos, library regulations, and national or international news. Some students use television in library to watch videos about debate and electoral system as preparation for the debate competition and election of student council leaders in school. The availability of Smart TV and internet network actually can be used by school as an alternative to digital screens that can display information and knowledge for teachers, staff and students. In other way, SMA Negeri Sumatera Selatan use social media such as WhatsApp, Instagram, Facebook and school websites as media to deliver information. The media for conveying new knowledge is more visible in reading literacy program called Sharing Book where teachers and students learn to seek, receive, study, process and share information more responsibly in order to avoid hoax news.

Increasing public involvement is carried out through digital literacy socialization programs, the stakeholder's involvement and strengthening of forums with parents or community. The socialization of digital literacy is one of activities in Life-Long Learning program, which is a seminar and internal training that is routinely held every Friday for SMA Negeri Sumatra Selatan students. Teachers and staff get socialization about digital technology through various trainings in SMA Rujukan program and also short training from private institutions on how to use platforms they have developed in online learning. The main support of the digital literacy implementation in SMA Negeri Sumatera Selatan is given by The South Sumatra Provincial Education who provide digital facilities and assist the digital literacy training. Bank Indonesia has also provided support for the implementation of digital literacy program through Bank Indonesia Mengajar program and build a BI Corner in SMA Negeri Sumatra Selatan's library. The involvement of parents in digital literacy program is formed in a digital communication network through WhatsApp group which is managed by the homeroom teachers. By joining this community, parents give contribution in 
monitoring students to use devices wisely and manage the time well by doing good things while they are at home.

Strengthening governance can be seen from the development of eadministration system and the making of school policies. Since 2009, SMA Negeri Sumatra Selatan has implemented a digital communication and information storage system via email, WhatsApp and intranet. In addition, SIMASTER application also is being used to manage the school management system, the Slims 8 application is for managing library books, and e-journal application is for school's shop finance management. However, there is no comprehensive digital administration system that covers all fields. Some cases still have to be processed manually, for example in the administrative process of organizing events, archives, proposals and reports of activities. The formulation of school policy for digital literacy is part of the planning step. The digital literacy program in SMA Negeri Sumatra Selatan is run based on a decree from the principal made in 2016 and 2018 as part of SMA Rujukan program. This decree is a follow-up to the regulation of the Minister of Education and Culture of the Republic of Indonesia Number 6 of 2016 concerning general guidelines for the distribution of government's grant for education and the agreement letter about government fund for SMA Rujukan between the curriculum sub-directorate of the directorate of Senior High School and SMA Negeri Sumatra Selatan. The decree of digital literacy is forwarded in more detail into Standard of Procedure and Work Instruction forms.

\section{Controlling}

Controlling is an action to make sure that the implementation runs according to plan (Kristiawan \& Safitri \& Lestari, 2017). The implementation of the digital literacy in SMA Negeri Sumatra Selatan does not have a special control system. The school receives supervision and evaluation from the Directorate of High School Development of the Ministry of Education and Culture of the Republic of Indonesia for the implementation of SMA Rujukan. The implementation of digital literacy activities can be seen from the report of SMA Rujukan that include time, place, realization, evaluation, and funding. Other 
digital literacy activities that are not included in SMA Rujukan are controlled by Academics and Quality Assurance and Development division. The academics division supervise the implementation of digital literacy carried out by teachers and students in learning. The form of supervisions can be seen through weekly evaluation meetings, annually Teacher Performance Appraisals, and teacher supervision for each semester that check the synchronization between planning, implementation and evaluation of learning. Quality Assurance and Development division conduct surveys to students regarding to the satisfaction of learning services from teachers, ICT facilities, and library services. This survey is also the application of ISO 9001: 2015.

\section{Conclusion}

The implementation of digital literacy governance uses management functions are planning, organizing, implementing and controlling. Planning is carried out by a research, program design meetings and proposal writing. Organizing is done through the formation of committee for digital literacy through SMA Rujukan program. Implementation is carried out by implementing the digital literacy strategy prepared by the Indonesian Ministry of Education and Culture in the book of Supporting Materials for Digital Literacy. SMA Negeri Sumatera Selatan do not control digital literacy specifically, but through the supervision and evaluation by the Directorate of High School Development of the Ministry of Education and Culture of the Republic of Indonesia for SMA Rujukan program, weekly evaluation meetings, teacher supervision, annually Teacher Performance Appraisals, and surveys from students.

\section{Acknowledgement}

We would like to express our special thanks and gratitude to the Acting Principal SMA Negeri Sumatera Selatan and Rector of PGRI University of Palembang who gave us the support to do this project. This project was funded independent. Secondly, we would like to thank the interviewees and friends who helped us a lot in finalizing this project. 


\section{References}

Adityar. (2017). Pengaruh Literasi Digital Terhadap Perilaku Internet Berisiko di Kalangan Siswa SMA dan MA di Kota Makassar [The Effect of Digital Literacy on Risky Internet Behavior Among High School and MA Students in Makassar City]. Magister Thesis. Hasanuddin University. http://digilib.unhas.ac.id/uploaded_files/temporary/DigitalCollection/ZDQy NGI0YTUyYTRmMjk2OGU3MzY0MTIINmEyNjMzMzQwYzdkM2QyYg $\equiv=$.pdf.

Amalia, R.R. (2015). Literasi Digital Pelajar SMA: Kemampuan Berkomunikasi dan Berpartisipasi Pelajar SMA Negeri di Daerah Istimewa Yogyakarta Melalui Internet [Digital Literacy for High School Students: The Ability to Communicate and Participate in State High School Students in the Special Region of Yogyakarta Through the Internet]. Journal of Studi Pemuda, 4(1), 224-240, https://jurnal.ugm.ac.id/jurnalpemuda/article/view/36733/23896.

Antoro, B. (2017). Gerakan Literasi Sekolah, Dari Pucuk Hingga Akar, Sebuah Refleksi [School Literacy Movement, From Top To Root, A Reflection]. Jakarta: Ministry of Education and Culture of Republic of Indonesia, https://setjen.kemdikbud.go.id/setjen/files/Buku Gerakan Literasi Sekolah.pdf.

Erwin, Y., Arafat, Y., \& Wardiah, D. (2021). Pemanfaatan Information and Communications Technology Sebagai Sumber Belajar di Era Digital [Utilization of Information and Communications Technology as Learning Resources in the Digital Age]. Jurnal Manajemen, Kepemimpinan, dan Supervisi Pendidikan, 6(1), 44-51, https://jurnal.univpgripalembang.ac.id/index.php/JMKSP/article/view/3951/3917.

Gilster, P. (1997). Digital Literacy. New Jersey: Wiley.

Isnandari, R. (2016). Manajemen Program Sekolah Islam Multitalenta dalam Membina Kecerdasan Intrapersonal Anak Berbakat Sains di SD Unggulan 'Aisyiyah Bantul [Multitalented Islamic School Program Management in Fostering the Intrapersonal Intelligence of Science Gifted Children at the 'Aisyiyah Primary School, Bantul]. Magister Thesis. Sunan Kalijaga State Islamic University. http://digilib.uin-suka.ac.id/23063/1/1420421028_BAB- 


\section{I_IV-atau-V_DAFTAR-PUSTAKA.pdf.}

JDIH. (2017). Undang-Undang Republik Indonesia Nomor 14 tahun 2005 [Law of the Republic of Indonesia Number 14 of 2005]. https://peraturan.bpk.go.id/Home/Details/40266/uu-no-14-tahun-2005.

Kartini, D., \& Yuhana. (2019). Peran Kepala Sekolah dalam Mensukseskan Program Literasi [Peran Kepala Sekolah dalam Mensukseskan Program Literasi]. Jurnal Manajemen, Kepemimpinan, dan Supervisi Pendidikan, 4(2), 137-144, https://jurnal.univpgripalembang.ac.id/index.php/JMKSP/article/view/2902/2734.

Kementerian Pendidikan dan Kebudayaan. (2016). Pedoman Pelaksanaan Gerakan Nasional Literasi Bangsa [Guidelines for the Implementation of the National Literacy Movement of the Nation]. Jakarta: Development Center of Language Development and Expansion Board of Ministry of Education and Culture of Republic of Indonesia. http://repositori.kemdikbud.go.id/55/1/Panduan-Gerakan-Literasi-Sekolahdi-SMA.pdf.

Kementerian Pendidikan dan kebudayaan. (2017). Materi Pendukung Literasi Digital [Digital Literacy Support Materials]. Jakarta: Ministry of Education and Culture of Republic of Indonesia. https://gln.kemdikbud.go.id/glnsite/wp-content/uploads/2017/10/literasiDIGITAL.pdf.

Kristiawan, M., Safitri, D., Lestari R. (2017). Manajemen Pendidikan [Education Management]. Yogyakarta: Deepublish.

Kurnia, N. (2017). Literasi Digital Keluarga, Teori dan Praktik Pendampingan Orang Tua terhadap Anak dalam Berinternet [Family Digital Literacy, Theory and Practice of Parental Assistance for Children on the Internet]. Yogyakarta: Center for Digital Society FISIP UGM. http://eksis.ditpsmk.net/uploads/book/file/3BAA7EF5-3BA7-4B8B-8594644DB1AC6AC9/bukuliterasidigitalcfds15p-180202081050.pdf.

Melani, R. (2019). Optimalisasi Implementasi Literasi Digital pada Pembelajaran Pendidikan Agama Islam (Studi Deskriptif di SMA Negeri 1 Nagreg Kabupaten Bandung) [Optimizing the Implementation of Digital Literacy in 
Islamic Religious Education Learning (Descriptive Study at SMA Negeri 1 Nagreg, Bandung Regency)]. Magister Thesis. Sunan Gunung Djati State Islamic University. http://digilib.uinsgd.ac.id/24930/.

Nopilda, L., \& Kristiawan, M. (2018). Gerakan Literasi Sekolah Berbasis

Pembelajaran Multiliterasi Sebuah Paradigma Pendidikan Abad ke-21 [Multiliterate Learning-Based School Literacy Movement A 21st Century Education Paradigm]. Jurnal Manajemen, Kepemimpinan, dan Supervisi Pendidikan, 3(2), 216-231, https://jurnal.univpgripalembang.ac.id/index.php/JMKSP/article/view/1862/1660.

Nurfadillah, E. (2018). Tata Kelola Pendidikan: Studi tentang Gerakan Ayo Sekolah di Kabupaten Bojonegoro Dilihat dari Perspektif Good Governance dan Sound Governance [Education Governance: A Study on the Ayo Sekolah Movement in Bojonegoro Regency from the Perspective of Good Governance and Sound Governance]. Undergraduate Thesis. Airlangga University. http://journal.unair.ac.id/download-fullpaperskmp765e92c545full.pdf.

O’Brien, D. \& Scharber, C. (2008). Digital Literacies Go to School: Potholes and Possibilities. Journal of Adolescent and Adult Literacy, 52, 66-68, https://news.cehd.umn.edu/wpcontent/uploads/2009/06/JAAL_obrien_scharber_2008.pdf.

Primasari, D. A. G., Maryani, S., Suparmanto, \& Juwita, D. (2019). Pemanfaatan TIK dalam menumbuhkan Karakter Religius Peserta Didik Sekolah Dasar di Gelumbang [Utilization of ICT in Growing the Religious Character of Elementary School Students in Gelumbang]. Jurnal Manajemen, Kepemimpinan, dan Supervisi Pendidikan, 4(2), 152-159, https://jurnal.univpgri-

palembang.ac.id/index.php/JMKSP/article/view/1862/1660.

Rahardjo, M. (2017). Studi Kasus dalam Penelitian Kualitatif: Konsep dan Prosedurnya [Case Studies in Qualitative Research: Concepts and Procedures]. Handout (pp.2-26). Malang: Maulana Malik Ibrahim State Islamic University. http://repository.uin-malang.ac.id/1104/1/Studi-kasusdalam-penelitian-kualitatif.pdf. 
Ratih \& Aline. (2015). Penumbuhan Budi Pekerti Lewat Kegiatan Non-Kurikuler [Character Development through Non-Curricular Activities]. Asah Asuh Magazine, 7(4). https://www.kemdikbud.go.id/main/uploads/default/documents/7.pdf,

Sholihah, K. (2016). Analisis Literasi Digital: Studi Pemanfaatan Jurnal Elektronik oleh Mahasiswa Magister Manajemen di Perpustakaan UKSW Salatiga [Digital Literacy Analysis: A Study on the Use of Electronic Journals by Master of Management Students at the SWCU Salatiga Library]. Tesis. Sunan Kalijaga State Islamic University. http://digilib.uinsuka.ac.id/23912/1/1420011034_BAB-I_IV-atau-V_DAFTAR-

PUSTAKA.pdf.

Sugiyono. (2012). Metode Penelitian Kuantitatif, Kualitatif dan $R \& D$ [Quantitative, Qualitative and R\&D Research Methods]. Bandung: Alfabeta. Wandasari, Y. (2017). Implementasi Gerakan Literasi Sekolah (GLS) Sebagai Pembentuk Pendidikan Berkarakter [Implementation of the School Literacy Movement (GLS) as a Former of Character Education]. Jurnal Manajemen, Kepemimpinan, dan Supervisi Pendidikan, 1(1), 325-343, https://jurnal.univpgri-

palembang.ac.id/index.php/JMKSP/article/view/1480/1291.

wearesocial.com. (2020, 30 January). Digital in 2020. https://wearesocial.com/digital-2020 